\title{
DP-1388
}

\section{REMOVAL OF CESIUM FROM SAVANNAH RIVER PLANT WASTE SUPERNATE}
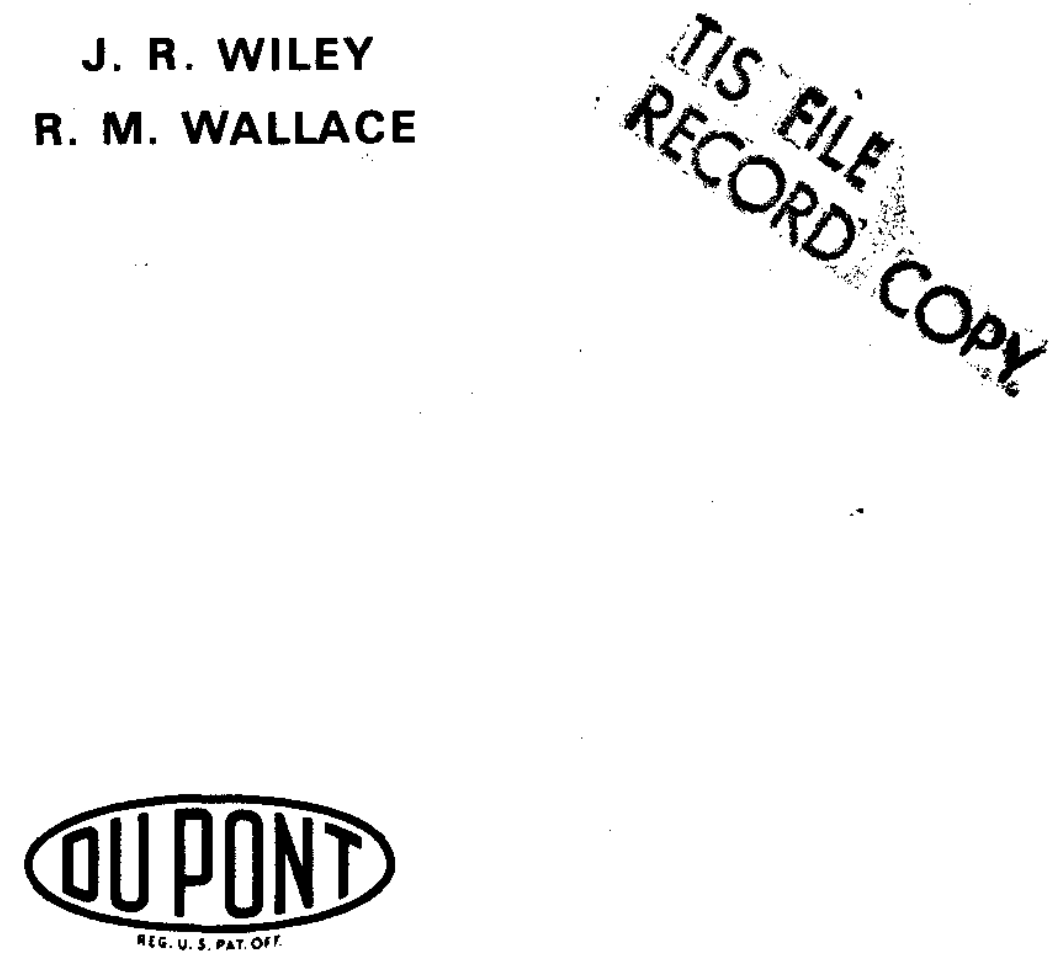

E. I. du Pont de Nemours \& Co. Savannah River Laboratory Aiken, S. C. 29801 


\section{NOTICE}

This report was prepared as an secount of work sponsored by the United States Government. Neither the United States nor the United States Energy Research and Development Administration, nor any of their contractors, subcontractors, or their employees, makes any warranty, express or implied, or assume any legal liability or responsibility for the accuracy, completenes or usefulness of any information, apparatus, product or process disclosed, or represents that its use would not infringe privately owned rights.

Printed in the United States of America

Avaitable from

National Technical Information Service

U. S. Department of Commerce

5285 Port Royal Road

Springfiald, Virginia 22161

Price: Printed Copy $\$ 4.00$; Microfiche $\$ 2.25$ 


\title{
REMOVAL OF CESIUM FROM SAVANNAH RIVER PLANT WASTE SUPERNATE
}

\author{
by
}

J. R. Wiley and R. M. Wallace

\section{Approved by}

W. H. Hale, Research Manager

Separations Chemistry Division

Publication Date: July 1975

E. I. du Pont de Nemours \& Co.

Savannah River Laboratory

Aiken, S. C. 29801

PREPARED FOR THE U.S. ENERGY RESEARCH AND DEVELOPMENT ADMINISTRATION UNDER CONTRACT AT(07-2)- 


\begin{abstract}
A process for separation and concentration of ${ }^{137} \mathrm{Cs}$ from Savannah River Plant waste supernate by using Duolite ARC-359 cation exchange resin was demonstrated with both synthetic and actual wastes. Tracer-level studies showed that Duolite resin efficiently sorbed cesium from a solution with composition expected for the plant process and that the resin could be cycled (load-elute-regenerate) repeatedly without damage. In column tests using actual waste supernates, $>99.99 \%$ of the ${ }^{137} \mathrm{Cs}$ was removed. Column throughput was correlated with feed composition by an empirical model. ${ }^{2}{ }^{37} \mathrm{Cs}$, eluted from the Duolite columns, was sorbed on zeolite for final solidification in concrete or glass. The overall volume reduction factor from cesium-salt solution to cesium-zeolite product is about 1400 .

Linde AW-500 zeolite sorbed cesium directly from waste salt solutions. Direct sorption is not recommended because 40 times more cesium-zeolite would be produced than by the Drolite process.
\end{abstract}




\section{CONTENTS}

Page

Introduction . . . . . . . . . . . . . . . . . . 5

Selection and Properties of Ion Exchange Resin . . . . . . 6

Effects of Feed Composition on Cesium Sorption . . . . . . 7

Distribution Coefficients . . . . . . . . . . 7

Empirical Mode1... . . . . . . . . . . 7

Column Test . . . . . . . . . . . . . . . 8

Tracer-Level Column Tests . . . . . . . . . . . 9

Effect of Potassium Ion on Cesium Sorption . . . . . . . . 12

Column Tests with Plant Waste. . . . . . . . . . . 13

Dissolution of Duolite Resin . . . . . . . . . . . . 15

Sorption of Eluted Cesium on Zeolite. . . . . . . . . 16

Direct Cesium Removal by Zeolite. . . . . . . . . . . . 16

Equilibrium Tests . . . . . . . . . . . . . 16

Column Tests. . . . . . . . . . . . . . . . 17

Conclusions and Future Work . . . . . . . . . . . 18

Acknowledgment . . . . . . . . . . . . . . . . . . 19

References . . . . . . . . . . . . . . . . . 19 


\section{LIST OF TABLES AND FIGURES}

Table

Page

1 Effects of Feed $\mathrm{Na}^{+}$and $\mathrm{OH}^{-}$on $\mathrm{Cs}^{+}$Sorption

by Duolite ARC-359 Resin . . . . . . . . . 8

2 Composition of Simulated Supernate . . . . . . . 9

3 Composition of SRP Waste Supernate . . . . . . . 13

\section{Figure}

1 Conceptual Waste Solidification Process . . . . . . 5

2 Cesium-Duolite Distribution Coefficients. . . . . . . 9

3 Apparatus for Column Tests . . . . . . . . . . 11

4 Sorption of Cesium on Duolite Columns in Series . . . 11

5 Elution of Cesium and Sodium from Duolite Resin . . . 12

6 Cesium Decontamination Factors for SRP Waste Supernate . . . . . . . . . . . . . 14

7 Elution of ${ }^{137} \mathrm{Cs}$ at Ambient Temperature . . . . . 15

8 Cesium-Zeolite Distribution Coefficients. . . . . . 17 


\section{REMOVAL OF CESIUM FROM SAVANNAH RIVER PLANT WASTE SUPERNATE}

\section{INTRODUCTION}

Studies are in progress at the Savannah River Laboratory (SRL) to determine methods for possible solidification and storage of Savannah River Plant (SRP) high-level liquid radioactive waste. In one of several options under consideration, solidified waste would be stored in an on-site, retrievable surface storage facility until the waste could be shipped to a federal repository.

An earlier report ${ }^{1}$ described in detail the origins and characteristics of SRP waste, the criteria for acceptable solid forms, and potential solid forms for SRP waste. That study was used to formulate the conceptual process outlined in Figure 1 .

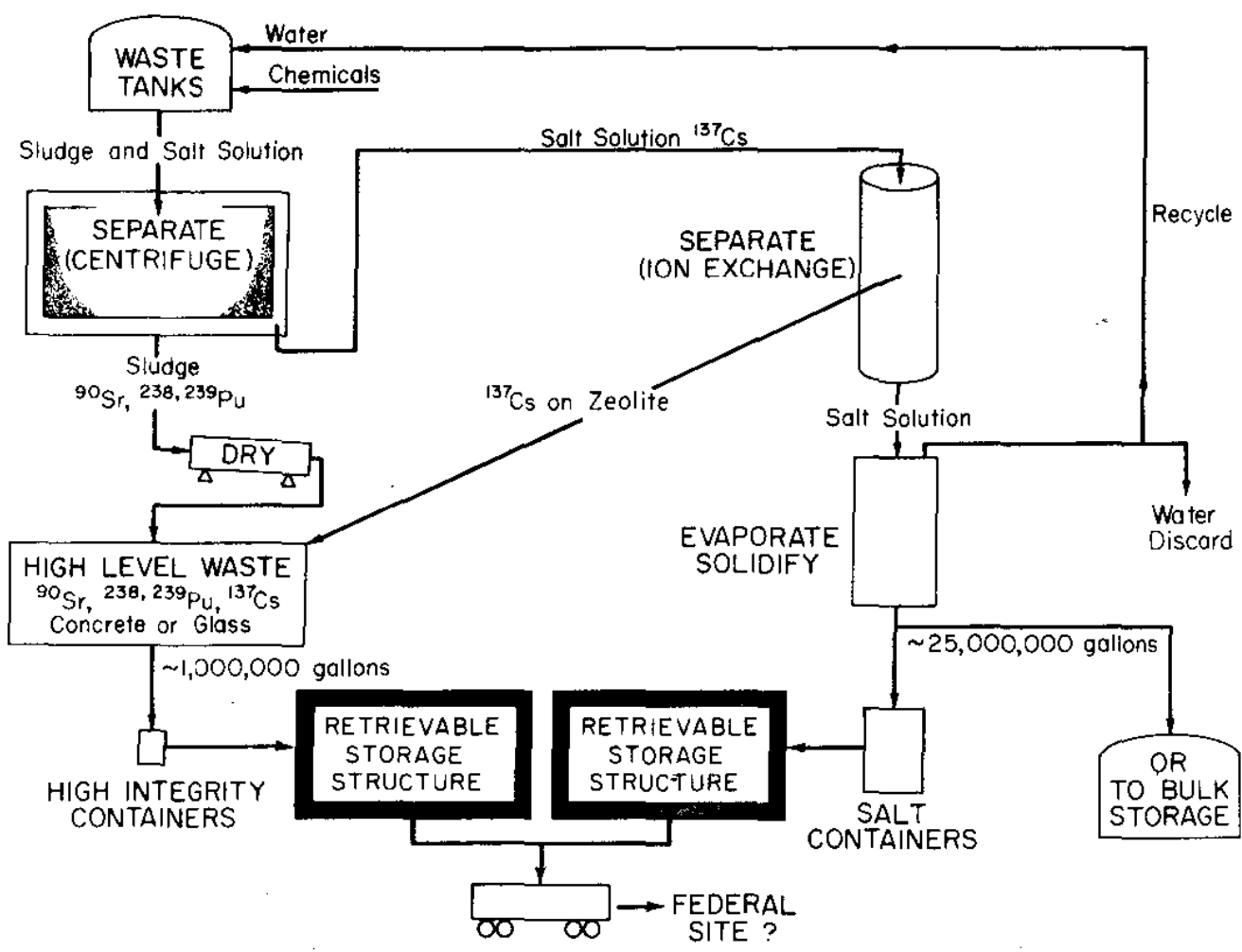

FIGURE 1. Conceptual Waste Solidification Process 
SRP waste, stored in underground tanks, consists of an alkaline salt solution, solid salt cake, and an insoluble sludge layer containing large amounts of iron, aluminum, manganese, uranium, and many other elements. In the conceptual process, waste would be removed from a tank by dissolving the salt cake with water and sluicing the slurry of sludge and solution from the tank. Sludge and solution would be separated by centrifugation and filtration. ${ }^{137} \mathrm{Cs}$, the principal biological hazard in the solution, would be removed by an ion exchange process and sorption on zeolite. Sludge would be washed to remove salts, dried, and blended with the cesium-zeolite for solidification into either concrete or glass.

The studies described in this report demonstrate the feasibility of removing ${ }^{137} \mathrm{Cs}$ from supernate by ion exchange and subsequent sorption on zeolite. Future reports will describe removal of other nuclides, such as ${ }^{90} \mathrm{Sr}$ and plutonium, from supernate, solidification of sludge and zeolite in concrete and glass, and demonstrations of other parts of the conceptual process.

\section{SELECTION AND PROPERTIES OF ION EXCHANGE RESIN}

Duolite* ARC-359, a phenolsulfonic acid cation exchange resin, was selected for cesium removal from SRP waste. Workers at Hanford ${ }^{2}$ found Duolite to be

- Reasonably selective for cesium

- Easy to elute

- Stable in alkaline solutions

- Undamaged by expected radiation exposure

Sodium-form, 20-50 mesh, Duolite resin (analytical grade) was used for the work described in this report. Total ion exchange capacity was determined by equilibrating 1 gram of Duolite resin, as received, with $1 \mathrm{M} \mathrm{NaOH}$, washing, and equilibrating with standard acid. The residual acid was then titrated with standard base. Duplicate determinations of resin capacity were 2.33 and $2.36 \mathrm{meq} / \mathrm{g}$.

Bulk density of wet resin was determined to be $0.63 \mathrm{~g} / \mathrm{cm}^{3}$ for the $\mathrm{Na}^{+}$form and $0.74 \mathrm{~g} / \mathrm{cm}^{3}$ for the $\mathrm{NH}_{4}^{+}$form. The ammonium form was obtained by equilibrating resin with $2 \mathrm{M}\left(\mathrm{NH}_{4}\right)_{2} \mathrm{CO}_{3}$ $2 \mathrm{M} \mathrm{NH}_{4} \mathrm{OH}$.

* Duolite is a trademark of Diamond Shamrock Chemical Co. 


\section{EFFECTS OF FEED COMPOSITION ON CESIUM SORPTION}

Although Hanford results ${ }^{2}$ indicated that Duolite ARC-359 resin sorbs cesium from solutions of widely varying compositions, quantitative understanding of feed composition effects is important for a plant process. Sodium, which competes with cesium for ion exchange resin sites, and hydroxide can affect cesium sorption; both are present in significant concentrations in plant waste. A systematic study of effects of these ions on cesium sorption was made.

Measured distributions of $\mathrm{Cs}^{+}$between resin and solutions containing 1 to $10 \mathrm{M} \mathrm{Na}^{+}$and 0.5 to $5 \mathrm{M} \mathrm{OH}^{-}$were used to develop an empirical model that can be used to predict breakthrough of $\mathrm{Cs}^{+}$.

\section{Distribution Coefficients}

The distribution of $\mathrm{Cs}^{+}$between solution and resin was determined in batch equilibrium experiments. The distribution. coefficient is

$$
K_{d}=\frac{(\overline{C s})}{(C s)_{e q}}=\left[\frac{(C s)_{o}-(C s)_{e q}}{(C s)_{e q}}\right]\left[\frac{m 1 \text { of solution }}{g \text { of resin }}\right]
$$

where $(\overline{\mathrm{CS}}),(\mathrm{Cs})$, and (Cs) are the cesium concentrations in the resin phase, initial solution, and equilibrated solution, respectively. $K_{d}$ is closely related to the number of column volumes of feed required to produce $50 \%$ breakthrough $^{3}$ (cesium.in instantaneous effluent $=50 \%$ of cesium in feed).

$\mathrm{K}_{\mathrm{d}}$ was determined in solutions containing $2 \times 10^{-4} \mathrm{M} \mathrm{Cs}^{+}$, $10^{5} \mathrm{dis} /(\mathrm{min})(\mathrm{m} 1){ }^{137} \mathrm{Cs}$, and varying concentrations of $\mathrm{NaOH}$ and $\mathrm{NaNO}_{3}$. At ambient temperature, $10 \mathrm{~m} 1$ of solution was equilibrated by shaking overnight with $1 \mathrm{~g}$ of Duolite ARC-359 resin ( $\mathrm{Na}^{+}$form). As shown in Table $1, \mathrm{~K}_{\mathrm{d}}$ decreased as $\mathrm{Na}^{+}$increased; $\mathrm{K}_{\mathrm{d}}$ increased as $\mathrm{OH}^{-} / \mathrm{NO}_{3}^{-}$increased at constant $\mathrm{Na}^{+}$.

\section{Empirical Model}

$$
\begin{aligned}
& \text { Values of } \mathrm{K}_{\mathrm{d}} \text { can be empirically fitted to the equation } \\
& \qquad \log \mathrm{K}_{\mathrm{d}}=\mathrm{n} \log \left[\mathrm{Na}^{+}\right]+\text {constant }
\end{aligned}
$$


Logarithmic plots of $\mathrm{K}_{\mathrm{d}}$ against $\left[\mathrm{Na}^{+}\right]$are linear with a slope of n. Plots of the data in Table 1 are shown in Figure 2. For simple ion exchange replacement of $\mathrm{Na}^{+}$by $\mathrm{Cs}^{+}, \mathrm{n}=-1$. However, the measured slope is steeper than -1 and becomes steeper as $\mathrm{OH}^{-}$increases. At high $\mathrm{OH}^{-}$concentrations, $\mathrm{K}$ is enhanced, possibly because anion-cation associations in the concentrated test solutions affect the activity coefficients of $\mathrm{Na}^{+}$ and $\mathrm{Cs}^{+}$differently. However, no completely satisfactory explanation of these results can be presented at this time.

\section{Column Test}

The model was evaluated in a laboratory test in which a solution containing $4.75 \mathrm{M} \mathrm{NaNO}_{3}, 1 \mathrm{M} \mathrm{NaOH}, 2 \times 10^{-4} \mathrm{M} \mathrm{Cs}^{+}$, and $10^{5}$ $\mathrm{dis} /(\mathrm{min})(\mathrm{m} 1){ }^{137} \mathrm{Cs}$ was passed through a $25-\mathrm{m} 1$ column $(1.3-\mathrm{cm}$ diameter) of Duolite ARC-359 resin at 1 column volume (CV) per hour. Breakthrough was $50 \%$ at 30 column volumes. The product of $\mathrm{K}_{\mathrm{f}}$ times the resin bulk density is approximately_equal to throughput at $50 \%$ breakthrough. ${ }^{3}$ For $5.75 \mathrm{M} \mathrm{Na}^{+}$and $1 \mathrm{M} \mathrm{OH}^{-}, \mathrm{K}_{\mathrm{d}}$ obtained from Figure 2 is 39 ( $39 \times 0.63=25 \mathrm{CV}$, in reasonable agreement with the experimental result of $30 \mathrm{CV}$ ). The relation between feed composition and column performance was further confirmed in tests with actual waste supernates ( 13 ).

TABLE 1. Effects of Feed $\mathrm{ila}^{+}$and $\mathrm{OH}^{-}$on $\mathrm{Cs}^{+}$Sorption by Duolite ARC-359 Resin

$\begin{array}{rcr}\mathrm{Na}^{+}, M & \text { OH- } M & K_{d} \\ 1 & 0.5 & 343 . \\ 2 & 0.5 & 142 \\ 3 & 0.5 & 78 \\ 4 & 0.5 & 57 \\ 5 & 0.5 & 40 \\ 1 & 1.0 & 462 \\ 2 & 1.0 & 199 \\ 3 & 1.0 & 100 \\ 4 & 1.0 & 70 \\ 5 & 1.0 & 45 \\ 2 & 2.0 & 371 \\ 3 & 2.0 & 176 \\ 4 & 2.0 & 110 \\ 5 & 5.0 & 347 \\ 6 & 5.0 & 205 \\ 7 & 5.0 & 132 \\ 8 & 5.0 & 90 \\ 9 & 5.0 & 66 \\ 10 & 5.0 & 48\end{array}$




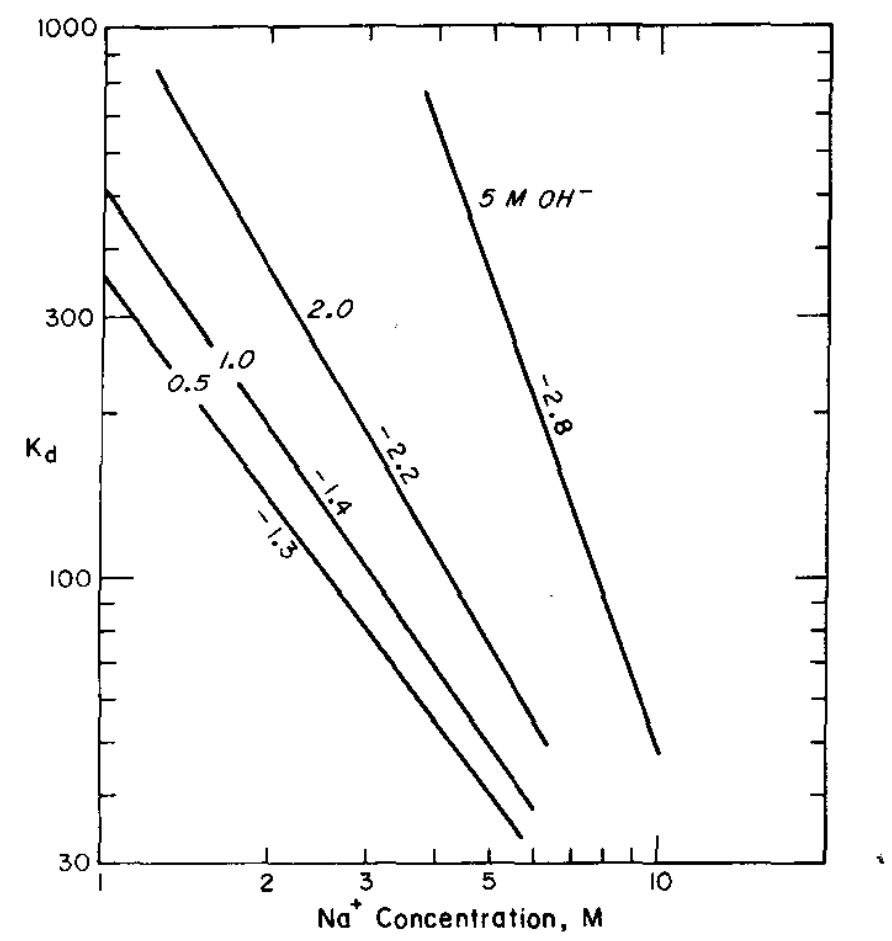

FIGURE 2. Cesium-Duolite Distribution Coefficients

\section{TRACER-LEVEL COLUMN TESTS}

Column tests were made using ${ }^{137} \mathrm{Cs}$ tracer to determine cesium decontamination factors (DF) ${ }^{*}$ as a function of column throughput and to determine the effects of several sorption-elution-regeneration cycles on cesium DF.

Simulated waste supernate with a composition (Table 2) similar to that expected for dissolved salt cake was used in these tests. ${ }^{1}$

TABLE 2. Composition of Simulated Supernate

$\begin{array}{ll}\text { Component } & \text { Concentration, } M \\ \mathrm{NaNO}_{3} & 2.2 \\ \mathrm{NaNO}_{2} & 1.1 \\ \mathrm{NaOH} & 0.75 \\ \mathrm{NaAlO}_{2} & 0.5 \\ \mathrm{Na}_{2} \mathrm{SO}_{4} & 0.3 \\ \mathrm{Na}_{2} \mathrm{CO}_{3} & 0.3 \\ \mathrm{CsNO}_{3} & 0.0002\end{array}$

${ }^{2} D F=\frac{{ }^{1{ }^{7} \mathrm{Cs} \text { in feed }}}{1{ }^{77} \mathrm{Cs} \text { in effluent }}$ 
The apparatus (Figure 3 ) used in these tests consisted of two 1.3-cm-ID glass columns filled with $25-\mathrm{ml}$ of $\mathrm{Na}^{+}$-form, 20-50 mesh, Duolite ARC-359 cation exchange resin. The same type of apparatus was used in column tests using actual SRP waste supernate (page 13 ).

Simulated waste containing actual plant waste supernate as a tracer, $4.4 \times 10^{5} \mathrm{dis} /(\mathrm{min})(\mathrm{ml}){ }^{137} \mathrm{Cs}$, was pumped downflow through the columns at $1 \mathrm{CV} / \mathrm{hr} .{ }^{*}$ Effluent from the first column was monitored with a GeLi gamma detector; ${ }^{137} \mathrm{Cs}$ activity in the monitor loop was calculated hourly by a PDP-15 computer. Effluent from the second column was collected with a fraction collector and subsequently analyzed for ${ }^{137} \mathrm{Cs}$ by gamma counting.

Figure 4 shows typical breakthrough curves from both columns.

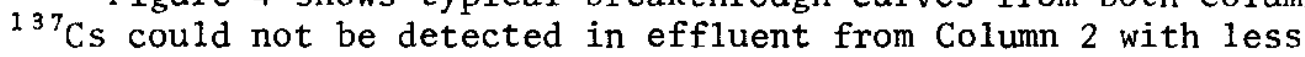
than $25 \mathrm{CV}(625 \mathrm{ml})$ feed throughput.

After 25 to $30 \mathrm{CV}$ of feed was passed through the columns, they were washed downflow with $5 \mathrm{CV}$ of distilled water at $1 \mathrm{CV} / \mathrm{hr}$. The columns were then heated to $55^{\circ} \mathrm{C}$ and eluted upflow at $1 \mathrm{CV} / \mathrm{hr}$ until all of the ${ }^{137} \mathrm{Cs}$ was removed. ${ }^{13{ }^{7}} \mathrm{Cs}$ in the eluate was monitored with the GeLi detector and PDP-15 computer. Figure 5 shows a typical elution curve. Very little ${ }^{137} \mathrm{Cs}$ eluted initially; its concentration in the eluate then increased abruptly and declined. After $12 \mathrm{CV}$ of elutriant was pumped through the columns, ${ }^{137} \mathrm{Cs}$ was not detectable in the eluate.

Figure 5 also shows the results of one test in which eluate samples were analyzed for sodium. About $25 \%$ of the $\mathrm{Na}^{+}$preceded the $\mathrm{Cs}^{+}$; this sodium fraction could be recycled to feed and thus increase the $\mathrm{Cs}^{+} / \mathrm{Na}^{+}$ratio in the eluate. This could reduce the total volume of cesium-zeolite by about $25 \%$.

After elution, the resin was regenerated at ambient temperature with $5 \mathrm{CV}$ of $2 \mathrm{M} \mathrm{NaOH}$. After seven complete load-eluteregenerate cycles were made, there was no noticeable deterioration in resin performance.

These tests showed that ${ }^{1{ }^{37} \mathrm{Cs}}$ can be efficiently removed from simulated waste supernate by sorption on Duolite ARC-359 resin. An overall DF of $>10^{4}$ was obtained with $25 \mathrm{CV}$ of feed (625 m1) using the two-column arrangement. Higher DFs could be attained by using additional columns.

* $\mathrm{CV}=1$ column volume, $25 \mathrm{~m} 1$. 


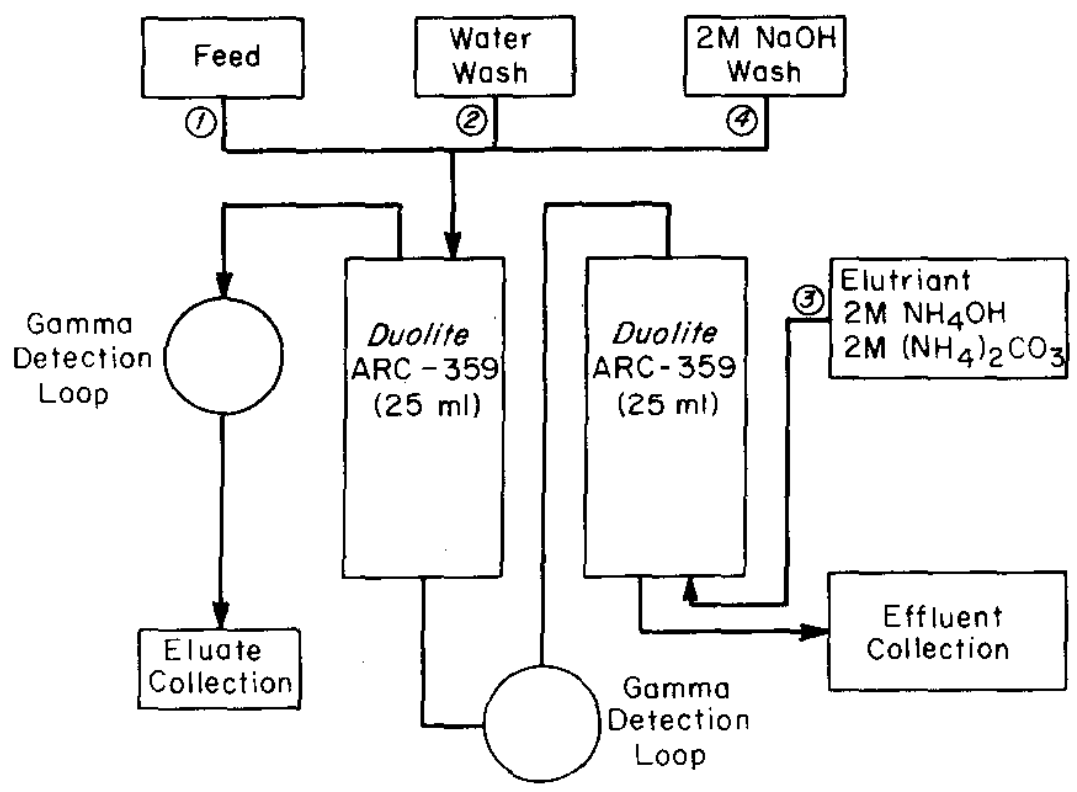

FIGURE 3. Apparatus for Column Tests

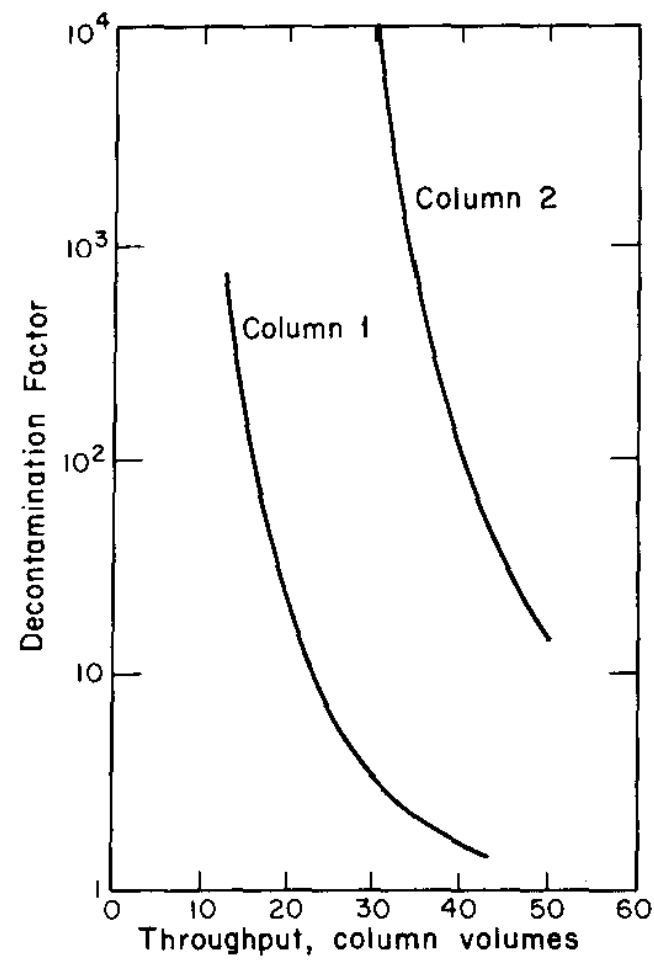

FIGURE 4. Sorption of Cesium on Duolite Columns in Series 


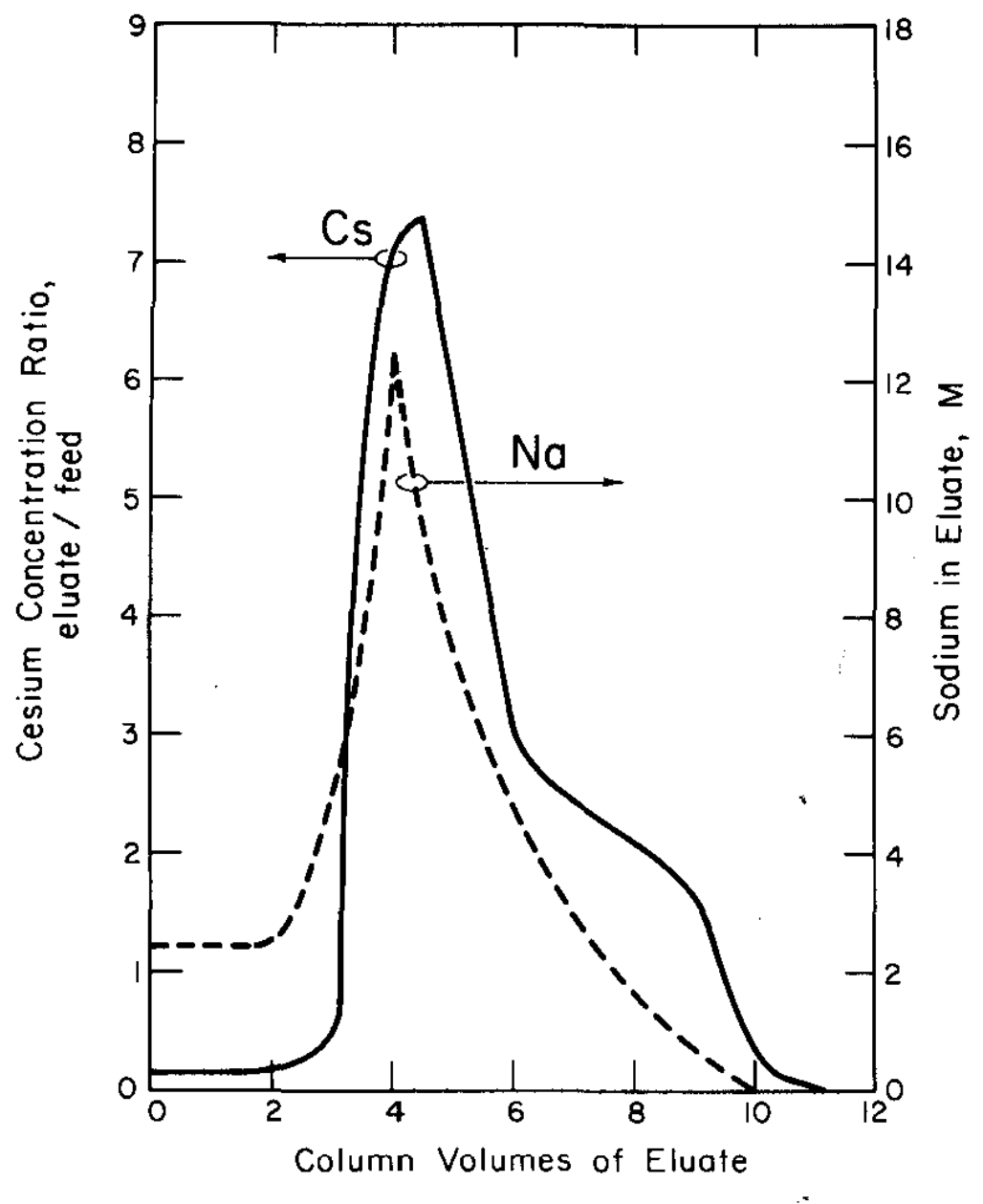

FIGURE 5. Elution of Cesium and Sodium from Duolite Resin

\section{EFFECT OF POTASSIUM ION ON CESIUM SORPTION}

Studies at Brookhaven National Laboratory using Linde AW-400* zeolite showed that potassium interfered severely with cesium removal. ${ }^{4}$ Similar tests with Duolite resin were therefore made. Addition of $0.01 \mathrm{M} \mathrm{KNO}_{3}$ to simulated supernate had very little effect on cesium removal; $0.06 \mathrm{M} \mathrm{KNO}_{3}$ reduced by about $20 \%$ the number of column volumes that could be processed. Plant wastes are expected to average $0.01 \mathrm{M} \mathrm{K}^{+}$. Thus, $\mathrm{K}^{+}$should not significantly interfere with cesium removal by Duolite resin.

* Linde is a trademark of Union Carbide Corporation. 


\section{COLUMN TESTS WITH PLANT WASTE}

Based on the previous tests with synthetic waste supernate, column tests were made to determine ${ }^{137}$ Cs DF using actual plant waste. Because waste supernate composition varies from tank to tank, samples from four waste tanks were obtained.

Supernate samples from $\mathrm{F}$ - and $\mathrm{H}$-Area SRP waste tanks were obtained to verify that Duolite ARC-359 could efficiently sorb cesium from actual plant waste. These samples contained high ${ }^{137} \mathrm{Cs}$ activity and concentrations of other ions and radionuclides spanning the range of concentrations of waste tank supernates. ${ }^{5}$ Compositions of samples obtained are given in Table 3. Tank 24 supernate was diluted to 1.5 times its original volume with water before processing in an attempt to match its concentration to that of simulated supernate. The other samples were untreated.

Tests were conducted in a shielded cell facility with an apparatus similar to that described on page 10. Supernates were drawn through a coarse (ASTM 40-60) filter funnel to remove possible particles and then pumped at $1 \mathrm{CV} / \mathrm{hr}(25 \mathrm{~m} 1 / \mathrm{hr})$ through the columns by $\mathrm{CCl}_{4}$ displacement from the feed reservoir. Pressure drop across the columns was normally about 1 psig. The pressure drop did not increase during these four tests; therefore, it is unlikely that the number of resin fines increased significantly. This indicates that the resin was not damaged by the very alkaline supernates or by radiation.

In each test, about $600 \mathrm{ml}$ of supernate was pumped downflow through the columns. The resin was then washed with $3 \mathrm{CV}$ of water at $1 \mathrm{CV} / \mathrm{hr}$, and then 7 more $\mathrm{CV}$ at $4 \mathrm{CV} / \mathrm{hr}$.. This ensured that all $\mathrm{NaAlO}_{2}$ present in the feed was removed from the resin. Otherwise precipitation of $\mathrm{Al}(\mathrm{OH})_{3}$ could occur during elution and plug the column.

TABLE 3. Composition of SRP Waste Supernate

$\frac{\text { Concentration, }}{\text { Tank } \mathrm{Na}^{\mathrm{t}}}$

$\begin{array}{rr}1 & 11 \\ 2 & 13 \\ 10 & 9 \\ 24 & 4\end{array}$

$\begin{array}{cccc} & & & \\ \mathrm{OH}^{-} & \mathrm{NO}_{3}^{-} & \mathrm{NO}_{2}^{-} & \mathrm{AZ}(\mathrm{OH} \\ & & & \\ 7.6 & 1.8 & 3.4 & 0.8 \\ 9.4 & 1.4 & 2.3 & 0.9 \\ 3.6 & 3.0 & 2.2 & 1.3 \\ 2.6 & 1.5 & 0.5 & 0.3\end{array}$

(H) ${ }_{4}^{-} \mathrm{SO}_{4}^{2-} \mathrm{CO}_{3}^{2-} \mathrm{PO}_{4}^{3-}$

0.01
0.01
0.02
0.01

0.13
0.09
0.18
0.13

0.06
0.07
0.01
0.02

\begin{tabular}{|c|c|c|c|}
\hline$\overline{1{ }^{37} \mathrm{Cs}}$ & ${ }_{106} \mathrm{Ru}$ & $90 \mathrm{Sr}$ & Gross \\
\hline$\left(10^{10}\right)$ & $\left(10^{8}\right)$ & $\left(10^{5}\right)$ & $\left(10^{4}\right)$ \\
\hline
\end{tabular}


Figure 6 shows ${ }^{137} \mathrm{Cs}$ decontamination factors obtained in these tests. In all of the tests, ${ }^{137} \mathrm{Cs}$ DFs of $10^{4}$ to $10^{5}$ were obtained with $10 \mathrm{CV}$ of feed. After $10 \mathrm{CV}$, DFs for the four supernates are in the order expected according to their $\mathrm{Na}^{+}$concentration. Tank 24 supernate, which had the lowest $\mathrm{Na}^{+}$concentration, gave the highest $D F$, followed in sequence by tanks 10 , 1 , and 2 . This result agrees with predicted feed concentration effects (page 7 ).

There is no theoretical reason why the curves in Figure 6 should intersect. Accepted ion exchange models predict concentric curves as the feed composition changes. ${ }^{3}, 6$ The intersections of the curves at high DFs are possibly a result of ${ }^{1{ }^{7} \mathrm{Cs}}$ cross-contamination between tests.

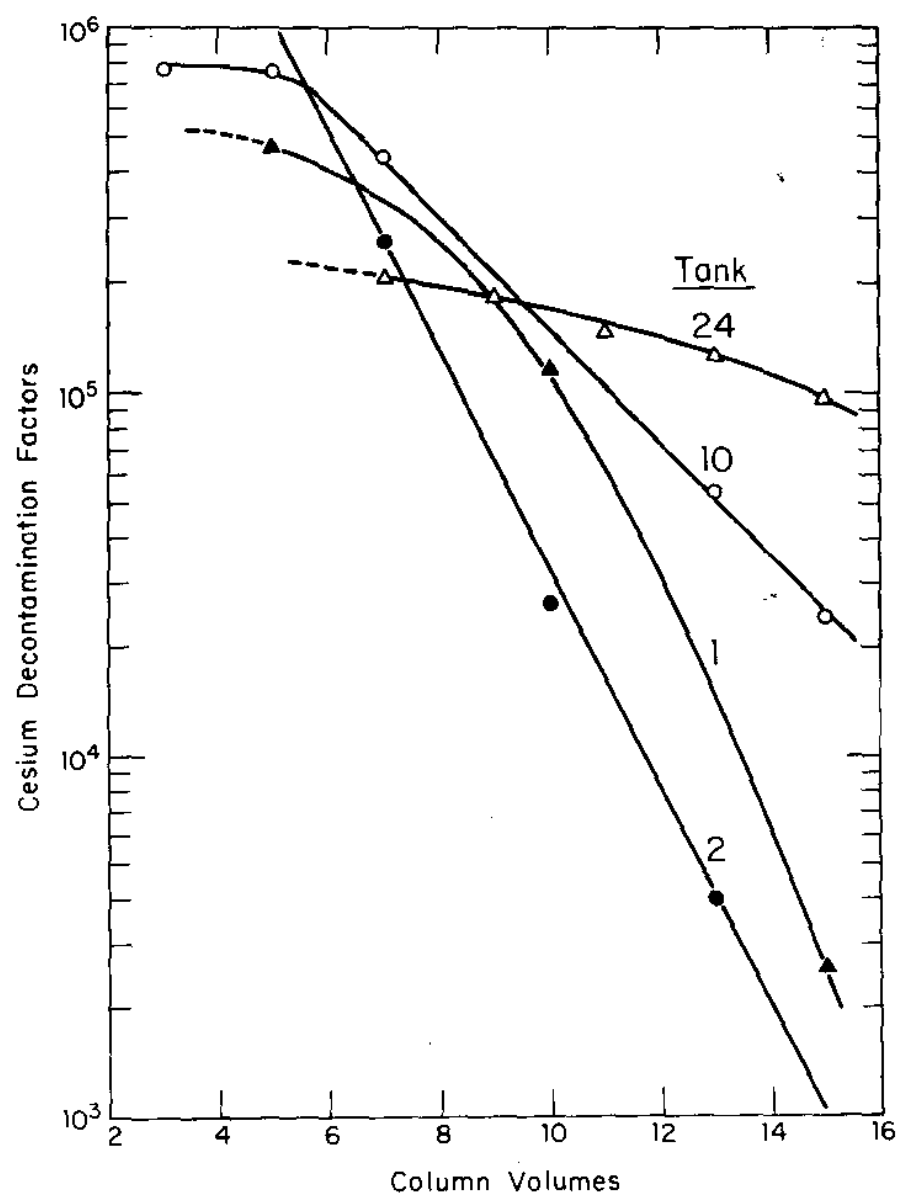

FIGURE 6 Cesium Decontamination Factors for SRP Waste Supernate 
In all of the tests, $295 \%$ of the ${ }^{137} \mathrm{Cs}$ was eluted with $8 \mathrm{CV}$ of $2 \mathrm{M}\left(\mathrm{NH}_{4}\right)_{2} \mathrm{CO}_{3}-2 \mathrm{M} \mathrm{NH}{ }_{4} \mathrm{OH}$ elutriant. Elutions $(1 \mathrm{CV} / \mathrm{hr})$ were performed at 25 and $55^{\circ} \mathrm{C}$; no differences in elution characteristics were noticed, and ambient temperature elution will suffice for the plant process. Figure 7 shows a typical elution curve.

After elution of ${ }^{13^{7}} \mathrm{Cs}$, the resin was regenerated at ambient temperature, downflow, with $10 \mathrm{CV}$ of $1 \mathrm{M} \mathrm{NaOH}$ at $1 \mathrm{CV} / \mathrm{hr}$.

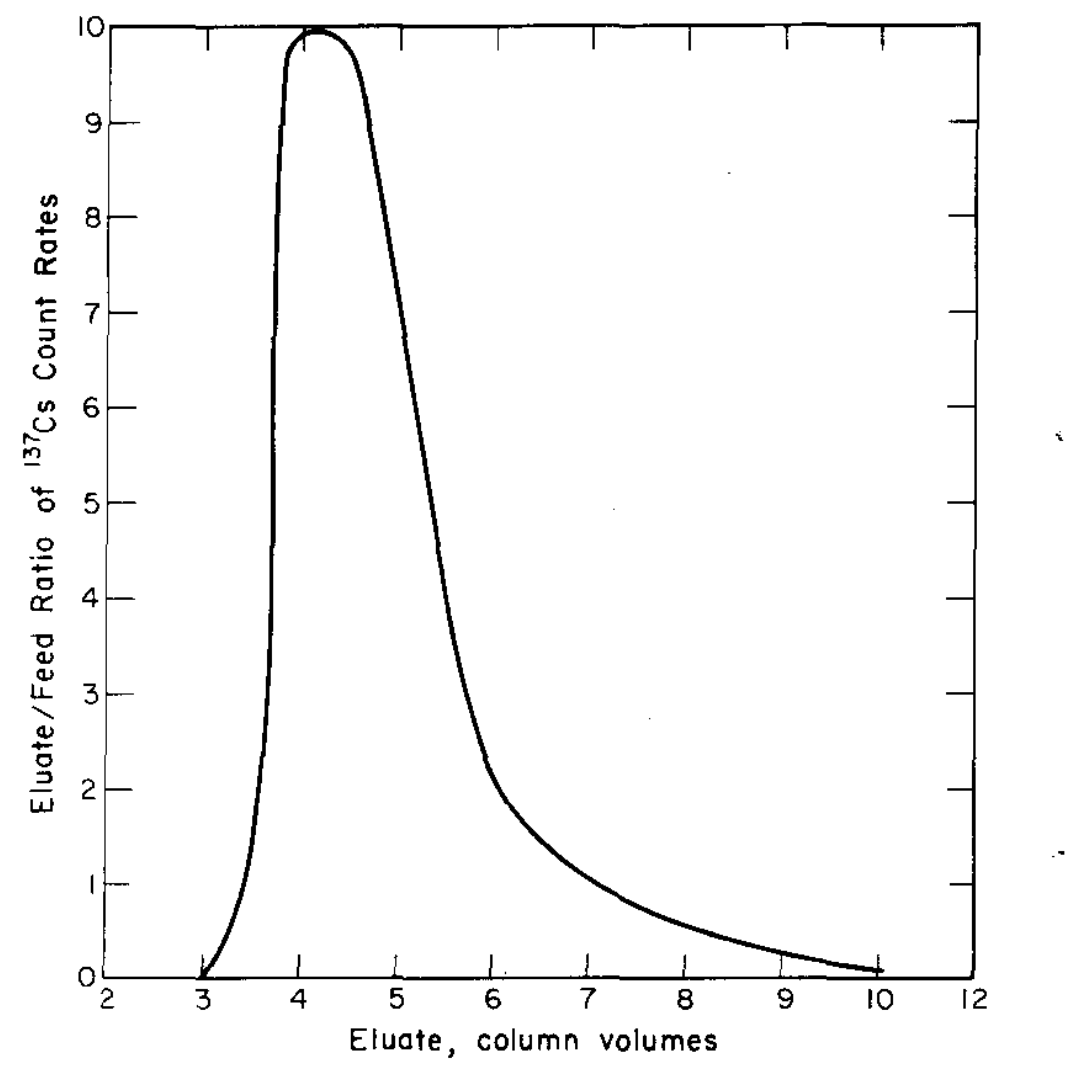

FIGURE 7. Elution of ${ }^{137} \mathrm{Cs}$ at Ambient Temperature

\section{DISSOLUTION OF' DUOLITE RESIN}

Spent resin from the Duolite columns must be disposed of by some method. Residual radioactivity on the ion exchange resin may preclude disposal in the burial ground. Because of this, a test was made to determine whether Duolite ARC-359 resin would dissolve by a known procedure. ${ }^{7}$ 
In this test, Duolite resin was digested in $0.1 \mathrm{M} \mathrm{HNO}_{3}-6 \%$ $\mathrm{H}_{2} \mathrm{O}_{2}$ at $80^{\circ} \mathrm{C}$; the resin completely dissolved in about $1 \mathrm{hr}$. After neutralization, this aqueous solution would be suitable for disposal with other 1iquid waste in the carbon steel waste tanks used at SRP.

\section{SORPTION OF ELUTED CESIUM ON ZEOLITE}

Eluate from the Duolite resin will be concentrated by steamstripping $\mathrm{NH}_{3}$ and $\mathrm{CO}_{2}$ and evaporating the remaining solution to approximately $2 \mathrm{M} \mathrm{Na}_{2} \mathrm{CO}_{3}-0.007 \mathrm{M} \mathrm{Cs}$. Cesium from this solution is sorbed on zeolite for subsequent mixing with sludge and solidification in glass or concrete. This sorption step was demonstrated by tracer-level column tests.

To ensure conversion to $\mathrm{Na}^{+}$form, $25 \mathrm{ml}(19.5 \mathrm{~g})$ of Linde AW-500, 20-50 mesh. zeolite was washed with $3 \mathrm{M} \mathrm{NaNO}$. The resin was rinsed with water and transferred to a 1.3-cm-ID column. $2 \mathrm{M} \mathrm{Na}_{2} \mathrm{CO}_{3}-0.007 \mathrm{M} \mathrm{CsNO}{ }_{3}\left[\right.$ with $1.7 \times 10^{5} \mathrm{dis} /(\mathrm{min})(\mathrm{ml}){ }^{\left.1{ }^{37} \mathrm{Cs}\right] \text { was }}$ pumped downflow through the column at $\mathrm{I} \mathrm{CV} / \mathrm{hr}$ at ambient temperature. $2 \%$ breakthrough (Cs in column effluent $=2 \% \mathrm{Cs}$ in feed) occurred after $70 \mathrm{CV} ; 20 \%$ breakthrough occurred after $76 \mathrm{CV}$. The zeolite was then washed with water at $1 \mathrm{CV} / \mathrm{hr}$. Effluent ${ }^{1{ }^{3}} \mathrm{Cs}$ was reduced to $1 \%$ of that in the $\mathrm{Na}_{2} \mathrm{CO}_{3}$ feed after $7 \mathrm{CV}$ of wash water and was not detectable after $10 \mathrm{CV}$.

These results show that it will be possible to sorb at least $70 \mathrm{CV}$ of concentrated Duolite column eluate on one zeolite column. After an initial water wash, further contact with water will not leach appreciable ${ }^{137} \mathrm{Cs}$ from zeolite.

\section{DIRECT CESIUM REMOVAL BY ZEOLITE}

Because direct sorption of ${ }^{1{ }^{37}} \mathrm{Cs}$ on zeolite would eliminate the Duolite columns, reduce costs, and also remove some plutonium and ${ }^{90} \mathrm{Sr}$ from waste supernate, tests were made to determine the feasibility of this approach.

\section{Equilibrium Tests}

Batch equilibrium measurements of the cesium-zeolite distribution coefficient, $\mathrm{K}_{\mathrm{d}}$, showed that Linde $\mathrm{AW}-500$ zeolite sorbs cesium from wastes of varied concentration.

Results shown in Figure 8 fit the equation

$$
\log \mathrm{K}_{\mathrm{d}}=\mathrm{n} \log \left[\mathrm{Na}^{+}\right]+\text {constant }
$$


and show the same trends as in Figure 2. Increased hydroxide concentration initially favors cesium sorption; however, zeolite is damaged by $>5 \mathrm{M}$ hydroxide. $0.01 \mathrm{M} \mathrm{K}^{+}$does not affect cesium sorption.

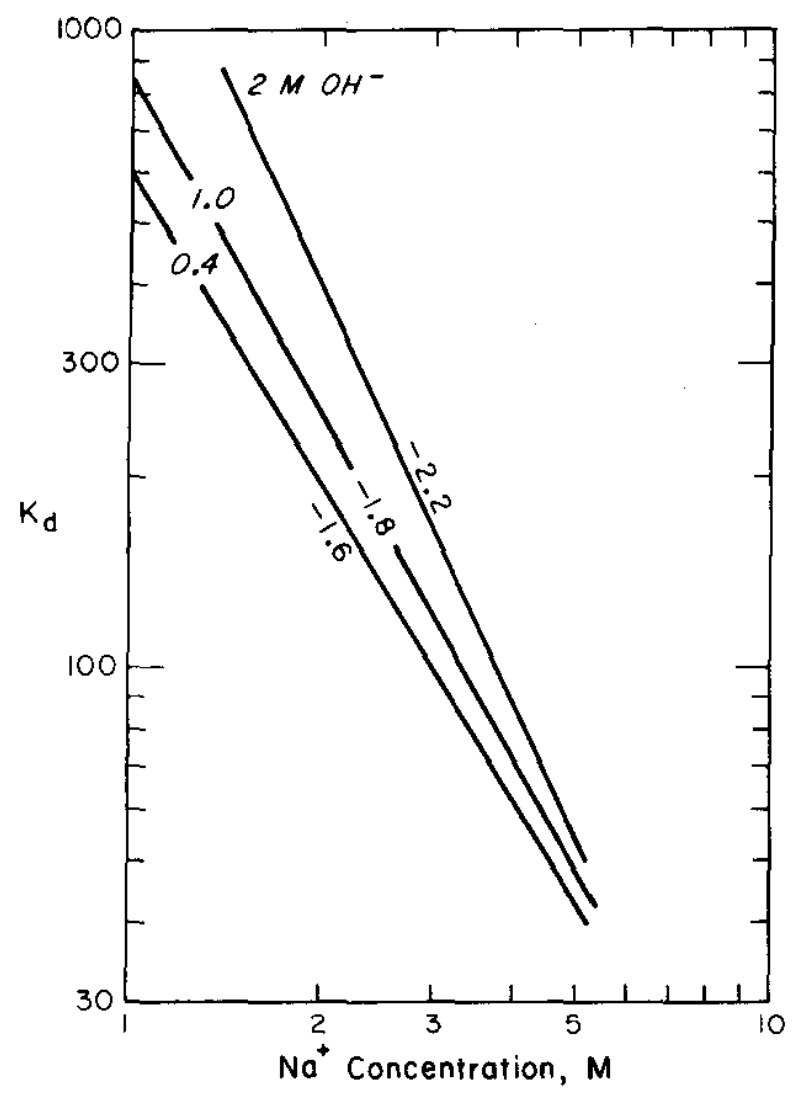

FIGURE 8. Cesium-Zeolite Distribution Coefficients

\section{Column Tests}

Tests were made to determine the number of column volumes (CV) of synthetic supernate that could be processed through a zeolite bed before cesium breakthrough. In a plant process, supernate would flow through two zeolite columns in series. At cesium breakthrough, the first column would be emptied. The partially loaded secondary column would replace the primary column, which would be loaded with fresh zeolite and used as the new secondary column. 
In the tests, two $1.3-\mathrm{cm}-1 \mathrm{D}$ columns were filled with $25 \mathrm{~m} 1$ of Linde AW-500, 20-50 mesh zeolite, which was converted to $\mathrm{Na}^{+}$ form by washing with $10 \mathrm{CV}$ of $1 \mathrm{M} \mathrm{NaOH}$. Synthetic supernate containing $10^{5} \mathrm{dis} /(\mathrm{min})(\mathrm{ml}){ }^{137} \mathrm{Cs}$ tracer was pumped downflow through the columns at $1 \mathrm{CV} / \mathrm{hr}$. Initially with 2 fresh columns, detectable

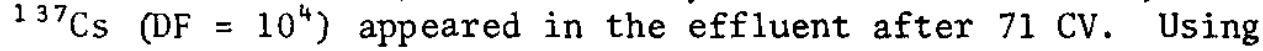
a partially loaded primary column reduced throughput to about $35 \mathrm{CV}$ for $\mathrm{DF}=10^{4}$. Column efficiency was not improved by either decreasing the feed rate or increasing column temperature.

These tests showed that cesium can be removed from waste supernate by direct sorption on zeolite. However, since only $235 \mathrm{CV}$ of supernate can be processed before zeolite is replaced, direct sorption would give a cesium concentration factor of about 35. The Duolite process would give a cesium concentration factor of about 1400 ( 20 by ion exchange and evaporation and 70 by sorption on zeolite). Because of the 40-fold increase in the amount of zeolite to be solidified in concrete or glass, direct sorption of cesium on zeolite is not recommended.

\section{CONCLUSIONS AND FUTURE WORK}

Tests demonstrated ${ }^{137} \mathrm{Cs}$ removal from SRP waste supernate by the two-column Duolite ion exchange process. Feed composition parameters affecting cesium sorption were identified and fitted to an empirical model. The entire ion exchange cycle was demonstrated successfully with both synthetic and actual waste. Direct sorption of cesium on zeolite is feasible, but this would generate 40 times more zeolite to be solidified in concrete or glass.

In future work, studies will be made to remove residual nuclides, such as plutonium and ${ }^{90} \mathrm{Sr}$, from SRP waste supernate. Also, effects of flow rate and column diameter will be determined. Finally, waste supernate separated from actual waste sludge by centrifugation and filtration will be processed. 


\section{ACKNOWLEDGMENT}

Unpublished results of J.S. Buckingham, Atlantic Richfield Hanford Company, were used as a basis for the beginning of this work. His work and suggestions are gratefully acknowledged.

\section{REFERENCES}

1. R. M. Wallace, H. L. Hull, and R. F. Bradley. Solid Forms for Savannah River Plant High-Level Waste. USAEC Report DP-1335, E. I. du Pont de Nemours \& Co., Savannah River Laboratory, Aiken, SC (1973).

2. Waste Management and Transportation Technology Development Quarterly Report, July 1974 through September 1974. USAEC Report ARH-ST-110A, Atlantic Richfield Hanford Co., Richland, WA (1974).

3. I. Hashimoto, K. B. Deshpande, and H. C. Thomas. "Peclet Numbers and Retardation Factors for Ion Exchange Columns." Ind. Eng. Chem. Fundomentals 3, 213 (1964).

4. H. Katz and M. Rothbart. Decontamination of Savannah River Waste Supermate by Ion Exchange. USAEC Report BNL-853 (T-339), Brookhaven National Laboratory, Upton, NY (1964).

5. R. S. Ondrejcin. Chemical Compositions of Supermate Stored in SRP High Level Waste Tanks. USAEC Report DP-1347. E. I. du Pont de Nemours \& Co., Savannah River Laboratory, Aiken, SC (1974).

6. F. Helfferich. Ion Exchange. McGraw-Hi1l, New York (1962).

7. N. E. Bibler and E. G. Orebaugh. "Iron-Catalyzed Dissolution of Polystyrenesulfonate Cation Resin in Hydrogen Peroxide." (Submitted for publication in Ind. Chem., Prod. Res. Develop.) 